\title{
CHILD PROTECTION WHEN TRAVELLING ABROAD
}

\author{
Rumenov Angelov MILEN \\ "Neofit Rilski" South-West University, Blagoevgrad, Bulgaria \\ milenang@abv.bg
}

\begin{abstract}
The article examines child protection when travelling abroad with only one parent or someone who is not a parent or a guardian set by national and EU legislation. It analyzes cases when one of the parents does not allow their child to travel abroad with the other one. Methods of protecting the children's best interests, as well as introducing the substitute consent have been presented. The development of the European Union's legislation and case-law on the subject are scrutinized. The study also covers the national legislation of the Republic of Bulgaria in the field of protecting the child's interests. The preconditions that have led to the legislative initiative on the adoption of Art. 127a of the Family Code referring to the court's consent to a child travelling abroad with only one of the parents are analyzed. Next, there are prerequisites leading to the adoption of the Interpretative Decision No 1 of 03.07.2017 at a General Meeting of the Civil Division of the Supreme Court of Cassation of the Republic of Bulgaria, which develops the framework in the field of granting a court permit for child's travelling. What is examined are the exact interests of the child that should be protected when the court gives the consent substituting the parental one. The case-law of the subject is followed in order to maximize its improvement in the protection of the rights and interests of the children living with one of their parents.
\end{abstract}

\section{Keywords: protection, travelling, abroad, children}

\section{European child protection experience}

In European law, a regulation has been introduced concerning the protection of children's rights, which has naturally led to the completion of the Bulgarian legislation in this respect. Examples in this regard are that, according to Art. $1, \S 1$, b. "b" and $\S 2$, b. (a) of Regulation (EC) No 2201/2003, the subject-matter includes disputes concerning the right to exercise parental and personal rights, as well as disputes concerning the appointment, exercise, delegation, limitation or revocation of parental responsibility. According to Art. 2, item 7 of the Regulation, the term "parental responsibility" includes all rights and obligations relating to the person or property of the child which are granted to a natural or legal person by virtue of a decision, by virtue of law or by virtue of an agreement having the same legal effect, including the right to exercise parental rights and the right to personal relations with the child. Art. 3, b. (d) of Regulation (EC) No 4/2009, of 18.12.2008, [1] provides that a court which, by virtue of the law, has jurisdiction to hear an action for parental responsibility, is competent to hear and determine the claim. Where the maintenance claim complements the claim for parental responsibility unless that liability is based solely on the nationality of one of the parties competent to hear and determine the maintenance claim, the court hears the application for parental responsibility to which the first claim has been joined. 
The matter has been supplemented by caselaw on similar disputes. According to a decision of 21 October 2015, in Case C$2015 / 15$ of the Court of Justice, the action of one parent requesting the court to replace the other parent's missing consent for the travel of his/her child outside his/her Member State of residence and the claim for the issue of a passport that child falls within the material scope of Regulation (EC) No 2201/2003, of the Council of Europe of 27 November 2003, on jurisdiction and the recognition and enforcement of judgments in matrimonial matters and the matters of parental responsibility, repealing Regulation (EC) No 1347/2000. [2]

Within the context of EU law, which in the present case is a prerequisite for enriching domestic legislation, it should be noted through the application of Regulation (EC) No 2201/2003 that the European Union has a limited role in the field of family law. The EU has only the right to adopt rules in areas where the treaties give it special competence. However, the EU has the competence to promote judicial cooperation on family law issues with cross-border implications. The EU's role is primarily to ensure that decisions taken in one country can be enforced in another, and which country is competent to deal with a specific case. The EU has adopted a number of regulations on judicial cooperation in the field of family law. These rules are based on the principle of mutual recognition - that is, decisions taken legally in one Member State must be recognized and enforced in other Member States and procedures should be as simple as possible. Precisely because of these preconditions, the Bulgarian court in the cases of parental rights and substitute consent in adopting its rulings adheres to the rule that competence must first be attributed to the Member State of the child's habitual residence, except in some cases the change of residence of the child under agreements between the holders of parental responsibility [3].

\section{Protecting children when traveling under Bulgarian law}

In the case of marriage annulment or termination of marital life, there raises the question of the exercise of parental rights as well as the imposed restrictions on the spouse who has been granted the right to perform a number of actions without the consent of the other husband. After the adoption of an entirely new Family Code (promulgated State Gazette, issue 47 of 23.06.2009, effective 1.10.2009) it was observed that it does not regulate the possibilities of one parent to carry out joint trips abroad with the child when no consent for such a trip is given. That is why a new article was created in the Family Code. 127a (State Gazette No. 100/2010, in force as of 21.12.2010), which aims at introducing the possibility for an action order to grant permission to the child to travel abroad with one of his/her parents, in the absence of an agreement of the other. According to Art. 127a of the Family Code competent in this case is the District Court at the current address of the child.

When granting a substitute consent for the travel of a child abroad, the Bulgarian court should examine in detail and on a case-bycase basis the details relevant to the requested consent. However, in this case, it is a formal judicial procedure, but we must not forget that it is a child who is often unable to defend his or her own interest. In order to protect the child, the Bulgarian court should strictly judge not only whether the formal conditions for giving a substitute consent are in place, but also provide for the majority of the consequences that would result from traveling abroad and the possible abuse of this right granted. Often, under the pretext that replacement consent is sought to be able for the child to travel and explore new places and cultures, it is actually intended to move the child abroad and never to return to the country again. The court, after giving its ruling, could not order an inspection - is the travel arrangement in place, and especially the 
return to the country, without being seized by the parent who has no contact with his child.

\section{Application of the substitute consent}

The introduction of the "substitute consent" has helped many parents who have not been able to travel abroad with their children so far without the consent of the other parent. This has inevitably led to the emergence of controversial case law on the issue. In some cases, the courts gave this substitute consent and allowed the child to travel with only one parent without the consent of the other. In other cases, the panels refused, with the argument of not interrupting the relationship of the child with his other parent, as well as for the purpose of prevention - not to abuse the right and going abroad not to live in another country and to obtain the situation known in the EU law as "child abduction" [4].

Due to such restrictions, the Bulgarian court also brought an action against Bulgaria at the European Court of Human Rights (ECHR). In the judgment of the ECHR in Penchevivs Bulgaria case, dated 10.02.2015. [5] it was accepted that the refusal of the Supreme Court of Cassation (SCC) as the last resort to allow unlimited removal from the country for a period of one year of a minor child accompanied by her mother without the consent of the father given by a Civil Case No 578/2011, of III, of the SCC constitutes an interference with the right to protection of the family life of the mother and the child within the meaning of Art. 8 of the Council of Europe Convention on Human Rights and Fundamental Freedoms. According to the ECHR, the reference to the SCC's consistent case-law, according to which a court cannot allow unrestricted travel abroad without a parent's consent, is defined as a "too formalist approach" for the interest and protection of the child. This was the real reason for the adoption of the Interpretative Decision of 03.07.2017, under Interpretative Case No 1/2016, of the
General Meeting of the Civil Division of the Supreme Court of Cassation.

In view of the interpretative ruling made, the courts in Bulgaria have already started in the preparation of judgments no longer to have the so-called "too formalistic approach" of the ECHR, but to analyze each case and they are alwaysguided in their motives by "the overriding interest and protection of the child." The intention of one parent to establish themselves at a fixed address in a country other than the habitual residence of the child seriously affects the interests of the child. This circumstance indicates a future change in living conditions not only for the child but also a change in time, place and frequency of contacts and relationships with the other parent. Changing the residence of each parent requires in each case to determine what is in the best interest of the child by thoroughly and in a good manner investigating by the court how the change will affect or change the conditions under which the child lives and develops [6].

\section{Adoption of an Interpretative Decision of the Supreme Court of Cassation}

Among the decision of the ECHR and the recommendation to Bulgaria, before the supreme judges, the question was asked what limitations, in view of the interests and protection of the child, the court should authorize by the order of art. 127a of the Family Code, traveling abroad without the consent of one parent. Supreme judges in the newly adopted interpretative decision stated that there is no way in deciding parents about whether their child can go abroad, the court can protect the best interest of the child if the trip is not foreseeable in time and space - i.e. it should be clear where the child goes - specific countries or certain countries, such as those from the European Union, and how long it will be abroad. "When granting a travel permit, the possibility of the child being taken to a place of unrest, in a place where the consequences of recent natural disasters 
have not yet been eliminated, or in a place where, although temporary, it is not advisable to travel. This would prevent the child from being put at risk. The judicial solution should also exclude the possibility for the Bulgarian state to be deprived of its mechanism of control over the actions of the parent to whom parental rights have been granted. In countries with which Bulgaria has no legal aid contracts that are not the EU Member States or the 1980 Hague Convention, on the civil law aspects of international child abduction or applying legislation other than the secular one, the Bulgarian State could not guarantee the execution of its own judgments on the implementation of measures for personal relations between the child and the parent who opposed the extradition abroad. This would in no way be in the best interest of the child and should be taken into account when discussing the issue of judicial authorization for travel" [7]. According to the practice of the EU Council, the concept of "best interests of the child" should be interpreted in the light of the objectives pursued by that Regulation. To ensure the best interests and protection of the child in the application of the jurisdiction rules introduced by Regulation (EC) No $2201 / 2003$, in the field of parental responsibility, the EU legislator used the proximity criterion, as it is clear from recital 12 of that regulation. By virtue of Art. 8 of Regulation No 2201/2003, jurisdiction in cases of parental responsibility shall be given first of all to the courts of the Member State of the child's habitual residence at the time the court is seized. Indeed, given their geographical proximity, these courts are usually in the best position to assess the measures to be taken in the best interests of the child [8].

In its interpretative decision, the Supreme Court of Cassation also states that the court should decide after a thorough and in-depth review of the particular family situation and of each of the factors of physical, emotional, psychological, material and medical nature, as well as to make a reasonable and balanced assessment of the interests of each of the parties and always follow the rule that the interests and protection of children are of paramount importance.

\section{Conclusion}

Family relationships, as well as those between parents and children, have always been very dynamic. Frequently, the development of the legal framework in this area has lagged behind the custom, and it has failed to timely regulate the gaps stemming from the rapidly evolving personal relationships. With regard to the mobility of modern citizens, related to the great awareness, liberalization of the markets and the freedom of movement of goods and capital, there are also few marriages and born children between parents of different nationalities. The regime of substitute consent must be extremely restrictive and this consent should be given exceptionally, rather than by law, to protect the child. This should be the prevention to stop possible abusive use of substitute consent. Because, in the case of misuse of this right, the lack of contact with his or her parent has as a mechanism only the action under Art. 126 of the Civil Procedure Act, the execution of which is effected by administrative procedure Art.126, para. 2, ex. 3 of the Family Code and which mechanism often takes a great dealoftime.

\section{References}

[1] Council Regulation (EC) No 4/2009 of 18 December 2008 on jurisdiction, applicable law, recognition and enforcement of decisions and cooperation in matters relating to maintenance obligations OB L 7, 10.01.2009. 
[2] Council Regulation (EC) No 2201/2003 of 27 November 2003 concerning jurisdiction and the recognition and enforcement of judgments in matrimonial matters and the matters of parental responsibility, repealing Regulation (EC) No 1347/2000 OB L 338, 23.12.2003.

[3] Order No 156 of 10 April 2018 of the Supreme Court of Cassation of the Republic of Bulgaria Civil Case No 1109/2018

[4] Convention of 25 October 1980 on the Civil Aspects of International Child Abduction

[5] Case of Penchevi v. Bulgaria 10 February 2015 European Court of Human Rights Strasbourg

[6] Decision No 34 of 21 March 2018 of the Supreme Court of Cassation of the Republic of Bulgaria Civil Case No 3368/2017

[7] Interpretative Decision No 1 of 03 July 2017 at a General Meeting of the Civil Division of the Supreme Court of Cassation of the Republic of Bulgaria

[8] Order No 156 of 10 April 2018 of the Supreme Court of Cassation of the Republic of Bulgaria Civil Case No 1109/2018 